\title{
DIÁLOGOS E MEMÓRIAS DE LUIZ GAMA E INTELECTUAIS NEGROS EM AÇÕES POLÍTICAS E CURRÍCULOS ESCOLARES NA CONTEMPORANEIDADE
}

\author{
Jeferson Mundim de Souzal
}

\section{RESUMO}

O presente artigo pretende dialogar com as memórias de Luiz Gama - intelectual negro que passou pela experiência de ter sido escravizado; baiano; filho de uma africana livre e de um pai branco que o vendeu como escravo e outras construções de intelectuais negros na perspectiva do saber científico e identitário que vem sendo esquecido nos currículos escolares, inviabilizando o respeito, a dignidade e o lugar de fala de negras e negros, baseados na ancestralidade, na oralidade, na cosmovisão africana e afro-brasileira que lutaram e continuam lutando na resistência, através de suas militâncias sociais com caráter identitário e seus objetivos sobre o campo da produção acadêmica de negros, contrariando paradigmas que tentam invisibilisar a história do negro, silenciando-o diante de regimes totalitários e coloniais. O desejo aqui é poder encontrar algumas formas para que Luiz Gama e outros autores negros cheguem aos livros didáticos e possam ser reconhecidos e celebrados com os valores a eles identificados para a constituição de uma formação escolar básica que contrarie a visão do "outro", do branco e do europeu, projetando os negros intelectuais brasileiros fora de cristalizações e estereótipos, que por muito tempo o animalizou, ignorando-o e perseguindo-o na tentativa de abafar seu lugar de fala.

Palavras-chave: Memórias. Negros. Currículos.

\section{DIALOGUES AND MEMORIES OF LUIZ GAMA AND BLACK INTELLECTUALS IN POLITICAL ACTIONS AND SCHOOL CURRICULA IN CONTEMPORARY TIMES}

\begin{abstract}
The present article intends to dialogue with the memories of Luiz Gama - black intellectual who has experienced the experience of being enslaved; baiano; son of a free African and a white father who sold him as a slave and other constructions of black intellectuals in the perspective of scientific knowledge and identity that is being forgotten in school curricula, rendering the respect, dignity and speaking place of blacks and black, based on ancestry, orality, African and Afro-Brazilian worldview that have fought and continue fighting in the resistance, through their
\end{abstract}

\footnotetext{
1 Doutorando em Língua e Cultura (UNIVERSIDADE FEDERAL DA BAHIA). Aluno do Programa de Pós-Graduação em Língua e Cultura - PPGLINC - UFBA. Orcid iD: https://orcid.org/00000002-5195-8580. E-mail: jefersonmundim@gmail.com
} 
social militancy with identity character and its objectives on the field of the academic production of blacks, contradicting paradigms that try to invisibilisar the history of the Negro, silencing it before totalitarian and colonial regimes. The desire here is to be able to find some ways for Luiz Gama and other black authors to come to textbooks and be recognized and celebrated with the values they identify for the constitution of a basic school education that contradicts the view of the "other", the white and European, projecting Brazilian intellectuals black out of crystallizations and stereotypes, which for a long time animalized him, ignoring him and chasing him in an attempt to stifle his speaking place.

Keywords: Memoirs. Black. Resumes.

\section{DIÁLOGOS Y MEMORIAS DE LUIZ GAMA E INTELECTUALES NEGROS EN ACCIONES POLIITICAS Y CURRÍCULOS ESCOLARES EN LA CONTEMPORANEIDAD}

\section{RESUMEN}

El presente artículo pretende dialogar con las memorias de Luiz Gama - intelectual negro que pasó por la experiencia de haber sido esclavizado; baiano; hijo de una africana libre y de un padre blanco que lo vendió como esclavo y otras construcciones de intelectuales negros en la perspectiva del saber científico e identitario que viene siendo olvidado en los currículos escolares, inviabilizando el respeto, la dignidad y el lugar de habla de negras y negros en la cosmovisión africana y afro-brasileña que lucharon y continúan luchando en la resistencia, a través de sus militancias sociales con carácter identitario y sus objetivos sobre el campo de la producción académica de negros, contrariando paradigmas que intentan invisibilizar la historia del negro, silenciándolo ante regímenes totalitarios y coloniales. El deseo aquí es poder encontrar algunas formas para que Luiz Gama y otros autores negros lleguen a los libros didácticos y puedan ser reconocidos y celebrados con los valores a ellos identificados para la constitución de una formación escolar básica que contraríe la visión del otro, blanco y del europeo, proyectando a los negros intelectuales brasileños fuera de cristalizaciones y estereotipos, que por mucho tiempo lo animalizó, ignorándolo y persiguiéndolo en el intento de sofocar su lugar de habla.

Palabras clave: Memorias. Negros. Currículos.

\section{INTRODUÇÃO}

Antes mesmo de escrever este artigo, entre meus pensamentos, práticas docentes e leituras compartilhadas na Universidade, sobre intelectuais negros e suas múltiplas relações de luta e resistência com o mundo, bem como as relações de poder enfrentadas pelos negros, já permeavam minhas ações e experiências no cotidiano escolar, fazendo-me 
refletir sobre a necessidade de pensar sobre elas, questionando-as e combatendo-as, com a finalidade de transformá-las.

Para isso, seria imprescindível analisar quais as possibilidades na construção de currículos que abordassem discussões como as diferenças de raça, de cultura, de gênero, as memórias de Luiz Gama e outras construções de intelectuais negros na perspectiva do saber científico e identitário que vem sendo esquecido nos currículos escolares, inviabilizando o respeito, a dignidade e o lugar de fala de negras e negros. O grande desafio seria a articulação da cultura do aluno com a cultura da escola, sem, no entanto, promover uma hierarquização entre estas, além do acesso a essas leituras e das mobilizações de intelectuais negros.

Comecei por compreender que a identidade da criança afrodescendente deve ser alicerçada desde quando ela ingressa na escola, ou seja, desde a pré-escola, e isso ocorrerá quando a escola e educadores compreendem que os alunos são indivíduos pertencentes a culturas diferentes, que são diferentes, mas não desiguais, e que a compreensão e o respeito à diferença são condutas indispensáveis.

Mas, ao me deparar com alguns livros didáticos de história, percebi que a história das trajetórias das matrizes negra e indígena é narrada sob o ponto de vista dos grupos sociais que a produziram. O "outro" demarcaria, então, o lugar do "diferente" sob o ponto de vista do narrador "branco". Nesse caso, a diferença seria inventada a partir de um ponto de vista determinado, ou seja, do ponto de vista de uma minoria que tem uma determinada cor - a cor branca - que, nas relações de poder entre os indivíduos e etnias que formaram a "pluralidade cultural" brasileira, foi imposto como hegemônico e dominante. O diferente é, então, uma invenção que irrompe na história e que precisa ser administrado, gerido, disciplinado e controlado.

Muitos questionamentos surgem ao lermos nos livros de história sobre como a África foi formada, seus povos, cultura, oferecendo-nos algumas perguntas, tais como: qual a imagem que temos da África? Como vemos a história dos negros no Brasil? 
A Professora Nilma Lino Gomes diz:

"... a geração brasileira, hoje adulta e que passou pela escola básica, foi formada? Certamente, pela visão do "outro", do branco, do europeu. A África e os negros brasileiros são vistos de forma cristalizada, estereotipada e, muitas vezes, animalizada. E mais, ao retomarmos essas imagens, hoje, elas vêm à nossa mente de forma isolada, desconexa, desarticulada de uma discussão mais ampla do contexto histórico, político e cultural da época..." (GOMES, 2008, p. 75).

O desconhecimento sobre a História da África é tão monumental quanto à dimensão deste continente. O contato dos europeus com os africanos se dá, ao longo dos tempos, em intrincados processos de encontros e confrontos, desde o século XV. No entanto, a complexidade das sociedades africanas organizadas em reinos, cidades-estados e territórios étnicos, que se reconheciam por outras denominações como Fanti, Ashanti, Peul, Mandinga, Fulani, Bambara, Tchokwe, Lunda, Kuba, Luba, Kosa, Zulu, entre outros, foi encoberta pelos colonizadores com a ideia de uma África relativamente homogênea, habitada simplesmente por "negros", em sua maioria, dominados por tribalismos submissos.

Outro ponto a ser discutido, também, a partir dos documentos oficiais do Brasil, são os desafios da implementação da Lei n 10.639/03, que torna obrigatório o ensino da História da África e da Cultura Afro-Brasileira nos currículos das escolas de educação básica, onde percebemos que a diversidade étnico-racial se apresenta cotidianamente nas relações interpessoais, no pertencimento étnico-racial da comunidade escolar, nas brincadeiras, nas diferentes formas de linguagens corporais e artísticas, nas práticas docentes, na arquitetura e localização da escola.

A escola não é uma instituição isolada da sociedade, portanto, produz e/ou reproduz contradições históricas, sociais, raciais e econômicas. Por isso que, a afirmação da identidade e marcação da diferença implica sempre nas operações de "incluir e excluir", ou seja, "nós" e "eles"; o que somos e o que não somos; quem está incluído e quem está excluído, o que indica a posição dos indivíduos nas relações de poder numa forte demarcação de fronteiras. Consequentemente, isto é uma forma de classificar as pessoas, 
dividi-las e atribuir diferentes valores aos grupos e assim classificá-los para hierarquizá-los.

Para compreendermos melhor o sentido da inclusão faz-se necessário ver a definição do termo "incluir" que vem do latim: includere, que significa "colocar algo ou alguém dentro de outro espaço/lugar". Esse verbo latino, por sua vez, é a síntese do prefixo in com verbo cludo, cludere, que significa "fechar, encerrar". Participa da origem desse verbo um substantivo em português. Trata-se do termo "claustro". Claustro é um espaço do qual alguns já "fazem parte" como "espaço delimitado, murado, rodeado". Há uma dialética entre a inclusão (o de dentro) e a exclusão (o de fora) como termos relacionais em que um não existe sem o outro. Excluir é tanto a ação de afastar como a de não deixar entrar.

É a partir dessas informações que podemos agora entender o motivo da exclusão dos povos indígenas e africanos na formação do povo brasileiro a partir da historiografia oficial assim como no currículo.

Observemos que o currículo não é um elemento neutro e desinteressado na transmissão de conteúdos do conhecimento social. Ele esteve sempre imbricado em relações políticas de poder e de controle social sobre a produção desse conhecimento. Por isso, ao transmitir visões de mundo particulares, reproduz valores que irão participar da formação de identidades individuais e sociais e, portanto, de sujeitos sociais.

O currículo vivenciado pelos alunos vai além dos conteúdos escolhidos para serem ministrados pelos professores. A existência, na experiência escolar, de um "currículo oculto" ao lado do currículo oficial está confirmada por vários estudos sobre o tema.

O conceito de "currículo oculto" como o conjunto de experiências não explicitadas pelo currículo oficial nos permite ampliar a reflexão sobre o tipo de mensagens cotidianas - traduzidas pelas páginas dos livros escolares, pelo preconceito racial entre colegas e entre professores e alunos - que são levadas ao conjunto dos alunos negros e mestiços. Ele inclui conteúdos não ditos, valores morais explicitados nos olhares e gestos, apreciações e 
repreensões de condutas, aproximações e repulsas de afetos, legitimações e indiferenças em relação a atitudes, escolhas e preferências.

Alguns relatos de trabalhos produzidos nesta linha revelam o nível de exclusão traduzido no plano da violência simbólica a que estes alunos estão submetidos na sua experiência escolar.

A crença de que o negro africano era inferior na escala humana foi a base do preconceito racial. O racismo científico assim explicava as diferenças culturais, como inferioridade racial, então, o preconceito racial expressa o sentido histórico de inferioridade gestado a partir das relações de dominação e subalternidade entre senhores e escravos durante quase quatrocentos anos de escravidão no Brasil que, como modelo econômico e social, fundou a sociedade brasileira - tanto no escravizado quanto no escravocrata.

No caso brasileiro, como nos aponta muito bem o antropólogo Roberto DaMatta (1987) é o preconceito racial de marca - isto é, aquele vinculado à aparência física, manifestações gestuais, etc. - que permite, em função do grau de mestiçagem, de indivíduo para indivíduo, decidir a sua inclusão ou exclusão na categoria de negro. Isto é o que se torna impossível frente ao preconceito racial de origem vivido nos Estados Unidos, como nos aponta DaMatta, segundo o qual a definição étnica está dada pela hereditariedade, independente do fato do indivíduo trazer ou não traços do fenótipo negro.

Os estudiosos que tratam das relações raciais e da questão do preconceito e da discriminação no Brasil enfrentam um problema básico na construção de uma categoria que, supostamente, abranja ou defina a população que é discriminada socialmente em virtude de sua ascendência indígena/africana. E este problema não é só dos estudiosos, mas também é percebido pela população negra e mestiça, ao ser convidado a se identificar em categorias como "raça" ou "cor". Na medida em que a negritude e a etnicidade são definidas como algo inferior, daí a dificuldade em se considerar indígena/negro no Brasil. 
O preconceito de raça e etnia é reforçado no convívio social; se acumula em todos os contatos sociais desde a primeira infância, passando pelo processo de socialização nos ambientes escolares. O preconceito racial é marcado pela desqualificação e pela inferiorização. A visibilidade corporal do negro anuncia outros significados discriminatórios que lhe são atribuídos, sempre marcados por um sentido de inferioridade; e esta visão é naturalizada no nosso cotidiano, como padrão predominante de comportamento social que nunca o questionamos e faz com que muitas pessoas não consigam enxergar o racismo no Brasil.

O preconceito racial se manifesta também na escola, não apenas pelas expressões racistas entre alunos ou entre professores e alunos, mas também pela omissão e pelo silêncio quando essas situações ocorrem ou, ainda, pelo mesmo silêncio e ocultamento da imagem do "negro" como imagem positiva e, ao contrário, pela valorização da imagem do "branco" dentro do currículo.

Dessa forma, os currículos são resultados de conhecimentos historicamente acumulados e caminhos percorridos por sujeitos, assim como os processos de aprendizagem estão vinculados aos processos de subjetividade. Portanto, temas como alfabetização, família e cidadania não são neutros e isentos das trocas de experiências e dos jogos hierárquicos das relações raciais.

Há que se reconhecer que a formação social, histórica, política, cultural e linguística é composta por diferentes matrizes étnico-raciais e isso não se resume a uma celebração acrítica da diversidade. Pelo contrário, a formação social brasileira é marcada por tensas relações históricas. Dessa forma, a formação do aluno para a cidadania e o mercado de trabalho também exige do professor (e da escola) o reconhecimento dessa complexa teia. A abordagem de tais temas deve respeitar os níveis de ensino e grau de compreensão dos/as alunos/as.

Nesse sentido, ao observarmos alguns dos instrumentos do currículo escolar ao longo da história da educação no Brasil, veremos que os conteúdos escolhidos pelo currículo escolar não legitimam a presença dos 
africanos como uma das matrizes fundantes na constituição do povo brasileiro. Este é um conteúdo restrito ao período da escravidão, e que, mesmo assim, apresenta o "afro-negro" como subalterno e inferior.

É essa questão, entre atitudes, conteúdos, abordagens e materiais que precisa ser urgentemente transformada na prática pedagógica da escola brasileira em respeito, reconhecimento e valorização da competência e dignidade de uma das matrizes fundadoras da nossa nação: a matriz negroafricana. Por isso, não podemos afirmar a ideia de uma cultura africana única ou mesmo "pura". Em se tratando de cultura, não há uma essência.

O que existe é um processo dinâmico de construção, que agora tentamos construir a partir da próxima seção para que a história, a cultura, os saberes e conquistas negras não sejam apagados dos currículos escolares, mas sim, reescritas e anunciadas em sua capacidade de visibilizar o que antes Ihes foi negado.

Portanto, comecemos pelas memórias e a biografia de Luiz Gama que tem sido objeto de estudos, aproximações e leituras ficcionais. São leituras e escritas traduzidas e interpretadas com as dificuldades de acesso a documentos e registros da época. No entanto, nenhum desses fatores retira o brilho daquele que foi o único intelectual negro que passou pela experiência de ter sido escravizado, sendo ele baiano; filho de uma africana livre e de um pai branco que o vendeu como escravo. Foi a primeira voz negra na literatura brasileira a denunciar os paradoxos sociais durante 0 período da escravatura, sendo protagonista de uma história que precisa ser conhecida pelos brasileiros e outras nações.

Gama lutou arduamente pelos direitos dos negros, 100 anos antes de Martin Luther King ser um líder nos Estados Unidos. A sua história, especialmente a experiência de ter vivenciado a escravidão, tem uma correspondência com a história de Frederick Douglass (1818-1895), ativista negro que foi um abolicionista e escritor nos Estados Unidos. Depois de escapar da escravidão em Maryland, ele se tornou um líder nacional do movimento abolicionista em Massachusetts e Nova York. Entretanto, nos Estados Unidos, não há um negro, um ativista, um intelectual que não 
conheça a história de Douglass. Aqui no Brasil, Gama ainda é profundamente desconhecido.

Esse fato não coloca uma linearidade temporal de desprestígio à história de Luiz Gama, mas retrata que sempre houve, entre outros fatores, pesquisadores e pesquisadoras, que lutaram e continuam lutando na resistência, através de suas militâncias sociais com caráter identitário e seus objetivos sobre o campo da produção acadêmica de negros, indígenas, mulheres, contrariando paradigmas que tentam invisibilisar a história do negro, silenciando-o diante de regimes totalitários e coloniais.

Gomes (2010), em Intelectuais negros e produção de conhecimento, irá exemplificar bem os caminhos percorridos de intelectuais negros que vêm lutando para apresentar formas de como alguns percursos da história étnico racial tem sido compreendida e apresentada com sequelas de apagamento:

São intelectuais, mas outro tipo de intelectual, pois produzem um conhecimento que tem como objetivo dar visibilidade a subjetividades, desigualdades, silenciamentos e omissões em relação a determinados grupos sociorraciais e suas vivências (GOMES, 2010 , p. 495).

Esse desconhecimento diz respeito à invisibilidade do pensador negro. Diante da singularidade dele como autor negro, nós vemos o peso da sua cor, vemos que o preconceito foi maior do que a vontade de enxergar o que ele era. Mas isso continua sendo perpetuado nos dias de hoje. Basta olhar para as nossas oligarquias em 2018, e ver que elas ainda são representadas pelos mesmos grupos com seus filhos, netos e bisnetos. Essa velha oligarquia é duradoura. Ela faz de conta de que está ouvindo as pessoas, mas não está. Esse não reconhecimento de Luiz Gama, entre outros intelectuais negros passa, obviamente, pelo racismo estrutural e institucional do Brasil e pela rejeição de movimentos populares.

Atualizar Luiz Gama em nossa contemporaneidade e inclúi-lo nos currículos escolares é buscar a configuração de outro perfil intelectual negro, visto que as tensões, os poderes, as reflexões invadem cenários acadêmicos e sociedade civil, indagando quem é esse intelectual negro hoje. Ele 
necessita identificar sua relação com a produção de um conhecimento dito engajado.

Gama fez isso muito bem em sua época, sendo advogado autodidata e profundo conhecedor jurídico, fazendo uso de diversas leis para lutar por justiça. Em sua saga abolicionista, "desenterrou" uma lei que não estava sendo colocada em prática. Sancionada em 1831, a Lei Feijó proíba a importação de escravos no Brasil, além de declarar livres todos os escravos trazidos para terras brasileiras a partir daquela data. A lei ainda estabelecia multas aos traficantes, além de oferecer um prêmio em dinheiro a quem denunciasse o tráfico.

A população brasileira, naquele momento, era majoritariamente descendente de escravizados. Quando ele começou a unir esforços com outros ativistas para fazer valer a lei, aquilo foi um assombro. Essa lei que não interessava aos donos de escravizados surgia em meio a uma sequência de pressões internacionais. Essa medida é uma das famosas "leis para inglês ver", ou seja, existia para dar uma satisfação à Inglaterra (que fazia pressão para o término do tráfico transatlântico), mas, na prática, o Brasil continuava traficando pessoas escravizadas.

Sendo assim, Gama contraria o pensamento de Bobbio (1997, p. 122), citado por Gomes, quando este vê o intelectual como aquele dotado de certo distanciamento entre a produção das ideias e o poder:

\footnotetext{
...uma posição de separação crítica de toda forma de domínio exercido exclusivamente com meios coercitivos, e que tendem a propor o domínio das ideias... em substituição ao domínio dos instrumentos tradicionais do poder do homem sobre o homem, e portanto, em última instância, a transformar a sociedade existente, considerada distante de mais da sociedade tal qual deveria existir (GOMES, 2010, p. 497).
}

Gama estará mais que inserido em seu contexto intelectual produtivo, em defesa de pessoas escravizadas, bem como se utilizará das estratégias de poder, através de seu aprendizado e acesso às leis que servirão de arma para combater as injustiças praticadas pelos "donos dos escravizados". 
Há relatos de que entraram mais de 700 mil africanos no Brasil, depois da lei Feijó, contrabandeados ao velho estilo brasileiro. Luiz Gama comprou essa briga. Os juízes 'escondiam' a lei para seguir protegendo os donos de escravizados. Era muito comum, naquela época, os proprietários modificarem o registro do escravizado como se ele tivesse chegado antes. Com atuação mais incisiva, fazendo uso da Lei Feijó, o ativista começou a ser seguido por muitos outros advogados e a fazer novos inimigos em São paulo.

Em seguida, outras leis tentaram proibir o comércio de escravizados, mas foram 'abafadas', como a Lei Eusébio de Queiroz (1850), que defendia o fim do tráfico. Nesse período, a maçonaria fortaleceu a luta de Gama. A Loja Maçônica América, da qual era membro fundador e contava com a participação de Rui Barbosa, à época estudante de direito em São Paulo, foi bastante ativa na causa republicana e abolicionista.

Assim, ao falarmos sobre Luiz Gama e os intelectuais negros, necessariamente me vejo inclinado a concordar e comparar algumas falas realizadas pela intelectual e feminista negra Bell Hooks, pois as reflexões dessa autora trazem contribuições para o debate sobre o engajamento do intelectual negro brasileiro. Segundo ela,

Nos círculos políticos progressistas, o trabalho dos intelectuais raramente é reconhecido como uma forma de ativismo; na verdade, expressões mais visíveis de ativismo concreto são consideradas mais importantes para a luta revolucionária do que para 0 trabalho mental. É a desvalorização do trabalho intelectual que muitas vezes torna difícil para indivíduos que vêm de grupos marginalizados considerarem importante o trabalho intelectual, isto é, uma atividade útil (HOOKS, 1995, p. 464-465).

Não diferente da época de Gama, visto que seu trabalho intelectual passou por grupos que tentaram duvidar, minimizar e desqualificar seu pensamento, intimidando-o por causa de sua história de vida, contrariando o ativismo que se impunha como forma de exercício do poder, Gama utilizou de sua intelectualidade e sabedoria para, em posse de descobertas e brechas na lei, defender, como forma de ativismo político, a negras e 
negros escravizados que o buscavam para a conquista de sua liberdade. Era sua luta revolucionária e incansável que se entrelaçava entre o fazer prático de sua profissão e a produção intelectual que viabilizaria a soltura de negros escravizados.

Outras produções intelectuais são conferidas a Gama, quando a partir do final dos anos 1868, ou seja, vinte anos antes da Abolição, ele começa a escrever uma série de artigos criticando os procedimentos de advogados e juízes, apoiando-se nas leis de 1831 e, depois, na de 1871, a Lei do Ventre Livre.

Nos seus eloquentes artigos de jornal, ele cria uma ponte e um contato com o leitor muito forte porque ele dizia que precisava mostrar o modo 'extravagante' como se praticava a justiça no Brasil.

Destacando um trecho de um artigo de Gama, escrito em 1880. "Se algum dia, os respeitados juízes do Brasil, esquecidos do respeito que devem à lei e dos imprescindíveis deveres que contraíram perante a moral e a nação corrompidos pela venalidade ou pela ação deletéria do poder abandonando a causa sacrossanta do direito e por uma inexplicável aberração faltarem com a devida justiça aos infelizes que sofrem escravidão, eu, por minha própria conta sem impetrar o auxílio de pessoa alguma, e sobre minha única responsabilidade aconselharei e promoverei não a insurreição - que é um crime, mas a resistência que é uma virtude cívica." Gama fazia muitos inimigos, mas tinha amigos poderosos e era figura muito popular.

Portanto, Gama como intelectual negro construiu sua trajetória de produção, reflexão e intervenção na interatividade entre o ethos político da discussão da temática da privação de liberdade - pessoas escravizadas e o ethos científico, adquirido em seu autodidatismo.

Em dezembro de 2015, a Ordem dos Advogados do Brasil deu a Gama o título póstumo de "profissional da advocacia". Na ocasião, seu tataraneto Benemar França, de 68 anos, recebeu a homenagem. No dia 17 de janeiro de 2018, ano que marca os 130 anos da abolição da escravatura, a Lei 13.629 declarou o advogado Patrono da abolição da escravidão do Brasil. 
O advogado autodidata se convertera em renomada autoridade na jurisprudência sobre escravidão. Terror dos fazendeiros e dos advogados e juízes corruptos, sua popularidade na província e em outros rincões do Império estava no auge, o número de inimigos também. Sua saúde era frágil. No momento em que escreve a carta, Gama sofria da diabetes que the ceifaria a vida em dois anos e talvez já suspeitasse que não veria as reformas que sonhara.

A resistência e insistência de Gama em fazer valer o direito diante das injustiças cometidas com seu povo, não só deu a ele visibilidade, mas também se criou inúmeras possibilidades de ameaças, obrigando-o a unir forças com outros ativistas para fazer valer a lei, aquilo que foi um assombro para sua época. Essa lei que não interessava aos brancos, donos de escravizados.

Assim, relembrar o legado do intelectual negro, Luiz Gama, é pensar também nas dificuldades que o próprio enfrentou para desfazer as injúrias e injustiças, cometidas pelos brancos e poderosos, diante de uma população grandiosamente negra. Ou seja, pensar no legado que a escravidão deixou para os negros é reviver os terrores de um tempo que não queremos lembrar. Mas, do ponto de vista da escravidão para o branco, segundo Bento:

É um assunto que o país não quer discutir, pois os brancos saíram da escravidão com uma herança simbólica e concreta extremamente positiva, fruto da apropriação do trabalho de quatro séculos de outro grupo (BENTO, 2003, p. 27).

Os benefícios concretos e simbólicos são visíveis, evitando-se caracterizar o lugar ocupado pelo branco na história do Brasil, como expressa Gama em uma de suas cartas:

Meu pai, não ouso afirmar que fosse branco, porque tais afirmativas, neste país, constituem grave perigo perante a verdade, no que concerne à melindrosa presunção das cores humanas: (...) [ele] pertencia a uma das principais famílias da Bahia de origem portuguesa. Devo poupar à sua infeliz memória uma injúria dolorosa, e o faço ocultando o seu nome. 
Este silêncio e cegueira relegados aos brancos permitem não prestar contas, não reparar, compensar, não indenizar os negros - se é que é possível, ou seja, são interesses econômicos que estão em jogo, superando essa consciência. Por essa razão, ainda hoje no Brasil, políticas compensatórias ou de ação afirmativa são taxadas de protecionistas, cuja meta é premiar a incompetência negra.

Assim como, demonstra Jodelet (1999, p. 27), "Políticas públicas direcionadas àqueles que foram excluídos de nossos mercados materiais ou simbólicos não são direitos, mas sim favores das elites dominantes".

Tal pensamento reflete a necessidade dessas elites em não aceitar que, quanto mais o negro ascende, mais incomoda, 'trocando de lugar' com o branco. O negro fora de lugar pode significar a ocupação do lugar que o branco acreditava ser exclusivamente dele.

Pierre Lévy buscou respostas para a pergunta: "Qual é a responsabilidade dos intelectuais face às novas tecnologias de comunicação"? Gama, em seu infinito esforço e dois séculos antes, lutou para encontrar as melhores maneiras possíveis em não só defender os escravizados, mas apresentar ao mundo homens e mulheres negras, dotados de grandes capacidades para manter-se vivo, criando, propondo e exigindo seu lugar de fala.

Poeta, jornalista, advogado e maçom, Gama cumpriu um destino incomum numa época impiedosa para pessoas de sua cor e condição. Desempenhou um papel pioneiro em vários campos. Na literatura, universo exclusivo de brancos, introduziu em 1859 uma voz até então ausente ao publicar sua obra única, as Primeiras Trovas Burlescas (PTB), coletânea de poemas satíricos nos quais um autor que se assume "negro" denuncia os paradoxos políticos, éticos e raciais da sociedade imperial.

$\mathrm{Na}$ política, exerceu incontestável liderança nas campanhas abolicionista e republicana, militando nos jornais, na tribuna e nos tribunais duas décadas antes do advento da Abolição e da República. No Direito, o advogado "provisionado" (com licença especial), inovou nas estratégias jurídicas, desenterrando leis como a de 7 de novembro de 1831, que 
declarava livres os africanos chegados ao Brasil a partir daquela data, combatendo a escravização ilegal.

Jamais frequentou escolas, pois, segundo ele, "a inteligência repele os diplomas, como Deus repele a escravidão". Os brasileiros esquecem que, cem anos antes de Martin Luther King, um negro, aqui, declarou ter um "sonho sublime: as terras do Cruzeiro, sem reis e sem escravos".

Tanto a obra poética de Gama quanto os artigos publicados nos principais órgãos de imprensa de São Paulo e da Corte são permeados por elementos autobiográficos. Porém, na diminuta correspondência conhecida, podem-se apreender aspectos mais íntimos e reveladores da "alma" de um homem que sempre se colocou como protagonista e agente da História com a qual se entrelaçava sua vida - vida que, particularmente numa carta, ele próprio se encarregou de contar. Em 25 de setembro de 1880, o renomado abolicionista responde às solicitações feitas pelo jovem amigo Lúcio de Mendonça, como se depreende das linhas iniciais: "Não me posso negar ao teu pedido (...): aí tens os apontamentos que me pedes, e que sempre eu os trouxe de memória".

Os "apontamentos" consistiam no relato sobre sua vida, desde o nascimento e infância na Bahia até o momento em que os dois homens se conheceram em São Paulo, em meados dos anos 1860.

Porém, as motivações do remetente e do destinatário, o teor e finalidade da carta, bem como a própria história do documento parecem simples, mas não são. Primeiramente, porque não se trata de mera curiosidade de um ou de confissões espontâneas do outro, embora seja evidente a cumplicidade entre os dois. Havia, por outro lado, uma premência pessoal e política. Apesar da diferença de idade, os laços de amizade se nutrem de afinidades diversas. Ambos participaram da fundação do Partido Republicano Paulista (1873).

Aos 26 anos, o também poeta, jornalista e advogado Lúcio de Mendonça, futuro fundador da Academia Brasileira de Letras, tinha grande prestígio em São Paulo, Rio e Minas Gerais. Aos 50 anos, Gama era, nas palavras de José do Patrocínio, o "grande chefe", "o símbolo da grande 
causa". De fato, havia mais de dez anos que realizava concorridas conferências, escrevia artigos polêmicos, encabeçava iniciativas para o alforriamento de escravizados promovidas pela influente loja maçônica América de São Paulo.

Mas, voltando à pergunta inicial, sobre qual seria a responsabilidade dos intelectuais e a inteligência possível do século XXI, retornamos a Luiz Gama, quem em sua época não só mobilizou, mas revolucionou, através de seus artigos, conferências e liderança contra a escravidão, sobrepondo-se diante de brancos com a sabedoria de leis que favoreciam a negros e negras escravizados. Até parecia um prenúncio para este século, quando Gama sempre conseguiu reunir entorno de si, intelectuais brancos de sua época, considerando, talvez aquilo que Pierre Levy, defendeu:

\footnotetext{
"eu defendia a ideia de que o papel principal dos intelectuais, em todas as culturas, inclusive a cultura mundial da emergente inteligência coletiva, é o de estudar os sistemas simbólicos com que as comunidades humanas vivem em simbiose e de preservar sua articulação, seu bom andamento e seu aperfeiçoamento" (LÉVY, 2007, p. 13).
}

Gama percorreu esse caminho, descobrindo brechas e argumentações que pudessem suscitar discussões que não só convenceram as autoridades da jurisprudência, mas que despertaram em muitos intelectuais de seu momento histórico, mobilizações a seu favor, desejando por parte de muitos, integrar essa luta. A prova disso é que, segundo jornais da época, o seu funeral em 24 de agosto de 1882 foi o maior já havido na cidade e movimentou a população paulistana, que the prestou as mais diversas homenagens. Entre os presentes, havia pessoas de diversas posições e classes sociais: do escravizado a personalidades ilustres, inclusive políticos adversários.

O que seria de Gama, estando sendo avaliado há mais de um século depois pelas discussões sobre "O papel público dos escritores e intelectuais", em Humanismo e crítica democrática?

Segundo Said (1981, p. 149): 
Muitas pessoas ainda sentem a necessidade de ver o escritorintelectual como alguém que deve ser escutado como guia no presente confuso e, ao mesmo tempo, também como líder de uma facção, tendência ou grupo disputando mais poder e influência.

Certamente ainda estaria buscando por definições de quem ou do que seria um escritor e intelectual, tornando-se mais confusa ainda por se tratar de um homem negro, outrora escravizado. Talvez para muitos, sem credibilidade, popularidade, cultura e pensamento.

Portanto, na linguagem do uso cotidiano, um escritor, nas línguas e culturas com as quais estamos habituados, é uma pessoa que produz literatura, isto é, um romancista, um poeta, um dramaturgo. Requisitos que Gama preenche, sendo ele intelectual para sua época, além do papel público que desempenhou diante das pessoas que o procurava para terem seus direitos respeitados.

Outro aspecto interessante, levantado em Said (1981, p. 163) são as possíveis respostas à pergunta: "por que razão, nesse e em outros contextos similares, os indivíduos e os grupos preferem escrever e falar a silenciar equivale a especificar o que o intelectual e o escritor confrontam na espera pública?".

Ou seja, existem pessoas que se preocupam com a justiça social, com a igualdade econômica e que compreendem que a liberdade deve incluir o direito a toda uma gama de escolhas que propiciam desenvolvimento cultural, político, intelectual e econômico. Isso motivará cada indivíduo a se articular em oposição ao silêncio. Portanto, o intelectual está em posição de tornar possível e fomentar a formulação dessas expectativas e desejos.

Luiz Gama foi esse intelectual, que, em função de seus poemas, nos quais satirizava a aristocracia e os poderosos de seu tempo, tornou possível o "não silenciamento". Um dos seus mais expressivos trabalhos é o poema "Quem Sou Eu?", que discutirá a temática da ridicularização do negro diante da sociedade e da sátira utilizada por Gama para expressar seu descontentamento com os critérios de valorização e desvalorização entre negros e brancos. Para ele, a miscigenação era algo tão complexo que os 
termos negro, branco ou mestiço parecem não resolver ou dar conta dessa complexidade. Daí a insurgente indagação: Quem sou eu? Ao mesmo tempo em que responde às ofensas ridicularizadoras dos escravocratas, chamando-os de bodes.

Quem Sou Eu? : (...) Se negro sou, ou sou bode/Pouco importa. O que isto pode?/Bodes há de toda casta/ Pois que a espécie é muito vasta.../Há cinzentos, há rajados,/Baios, pampas e malhados,/Bodes negros, bodes brancos,/E, sejamos todos francos,/Uns plebeus e outros nobres./Bodes ricos, bodes pobres,/Bodes sábios importantes,/E também alguns tratantes...

Por mais estratificada que fosse a sociedade paulistana, ninguém escapava da bodarrada. Esse poema quer demonstrar que os papéis e as relações sociais entre os indivíduos não poderiam ser sustentados pela superioridade/ inferioridade racial, uma vez que a cor se apresenta como um significante vazio. Há, aqui, um chamamento social para se repensar o lugar do preconceito de cor com base em purezas raciais numa sociedade miscigenada.

Em resumo, um dos preconceitos racistas mais difundidos dizia (e diz) respeito ao suposto odor que proviria dos negros. Por isso, no Brasil do século XIX, uma das gracinhas mais comuns era chamá-los de "bodes".

Ao invés de tremer de rancor e babar de raiva, sinais histéricos de impotência, Luiz Gama preferiu colocar no ridículo (silenciar) essa "gentalha". Sinteticamente, como disse ele em outra oportunidade, "todo mundo tem a mesma catinga".

Se as dificuldades e incertezas vividas por Gama foram tamanhas para escrever, ser ouvido, encontrar seu lugar de fala e ser reconhecido como intelectual, imaginemos como não seria hoje, a partir do texto de Adauto Novaes, em "intelectuais em tempo de incerteza", onde a discussão sobre o silêncio vem incomodando tanto e criando espaços para pensar no silêncio como uma espécie de substância secreta que abre caminho à expressão.

Sendo assim, Novaes (2006, p. 7-8) afirma,

O silêncio é, pois, constitutivo da fala, impressão interrogativa, análoga a um olho nas trevas "que nada vê, mas se sente prestes a

Revista Exitus, Santarém/PA, Vol. 10, p. 01-25, e020018, 2020. 
ver". Ele designa uma presença que pede para ser desvendada. Qualquer palavra, qualquer frase sempre guarda uma perspectiva imaginária e uma dimensão obscura, presença alusiva.

Luiz Gama se valeu de sua fala, tentando ver "nas trevas", as possibilidades de derrubar murros e amarras, porque sempre acreditou ser ela, sua companheira e constitutiva de que por trás dela sempre poderia existir algo a mais, desvelando assim caminhos de liberdade e expressão de sentimentos.

É como se Gama jamais pudesse tirar os olhos do pensamento acumulado ao longo de sua história e suas profundas lembranças, e também como se tivesse medo daquilo que não se poderia saber ainda. Portanto, tempos de incertezas.

Para que nosso passado esteja bem relembrado nas memórias e que possamos lutar a cada dia como intelectuais negros, assim como fez Gama, a primeira atitude, segundo said (2009, p. 170) "é impedir o desaparecimento do passado, proteger-se contra esse dano que, na rapidez da mudança, na reformulação da tradição e na construção de expurgos simplificados da história".

Mas também que saibamos lutar pela construção de campos de coexistência, em lugar de campos de batalha, como o resultado do trabalho intelectual, que fazemos e que Luiz Gama utilizou-se, em forma de poesia, revertendo determinados contextos à sua condição, usando de imagens satíricas ao se retratar a sociedade branca, em: o "Orfeu de carapinha".

Lembrando a figura do poeta grego Orfeu, e aludindo ao seu cabelo crespo, Gama foi chamado de "Orfeu de carapinha", e dominava tanto a poesia lírica, quanto satírica.

Sua poética transcorre na primeira pessoa, sem esconder a própria origem e sem deixar de proclamar sua negritude; ao lado disto, não deixa de usar as imagens tradicionais de seu tempo, como as evocações mitológicas (tais como Orfeu, Cupido etc.) ou aos poetas do passado (como Lamartine, Camões, por exemplo). 
Contudo, Gama reverte essas imagens à sua condição: a musa é da Guiné, o Orfeu tem carapinha. Ao retratar a sociedade branca, usa de imagens fortemente satíricas:

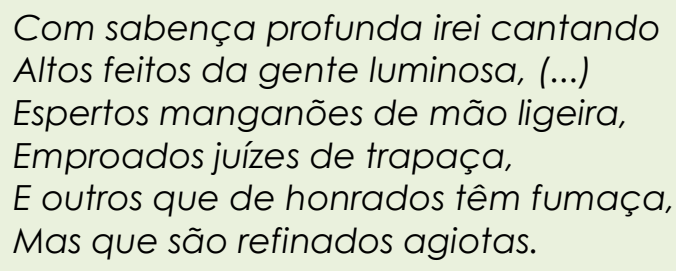

Gama apresenta-se como um intelectual com a voz da imaginação. Fez apelo ao devir, à memória, à tradição, à saudade, ao sentir-se desterritorializado. Conviveu com a experiência do "exílio" e da "perda", fazendo-o sentir "estrangeiro" e "familiar" no espaço que habitou.

Mais do que poemas introspectivos, Gama apresenta, em suas produções, os efeitos físicos e psicológicos sobre aqueles que vivenciaram o horror da escravidão, cuja identidade foi forjada no mundo moderno ocidental.

Na recorrência a Luiz Vaz de Camões, em Os Lusíadas, notamos que aí está sua principal fonte de inspiração para o estilo épico e uso de imagens heroicas. Sebastianismo e diáspora, apesar de se constituírem como eventos históricos díspares, apresentam aspectos em comum: a ideia de um passado que pode ser recuperado, a dor e o sofrimento a partir de um sentimento de perda.

Ele constrói, a partir dos elementos da cultura branca, a antítese para a cultura e civilização dos negros, preenchendo-os com elementos da poesia tradicional; assim, contrapõe-se a "musa da Guiné" ás musas grecoromanas; o granito escuro ao branco mármore; a marimba e o cabaço à lira e à flauta:

Ó Musa da Guiné, cor de azeviche,

Estátua de granito denegrido, (...)

Empresta-me o cabaço d'urucungo,

Ensina-me a brandir tua marimba (...) 
Sobre si mesmo traça, nos seus versos, uma imagem que longe está da figura do "pobre coitado" ou sofredor que figura nos negros pintados por poetas brancos contemporâneos como Castro Alves, Gama atinge-se com a mesma crítica feroz com que ataca o sistema, menosprezando seu próprio valor ante os padrões culturais vigentes, que ele implicitamente aceita.

\author{
Se queres, meu amigo, \\ No teu álbum pensamento \\ Ornado de frases finas, \\ Ditadas pelo talento; \\ Não contes comigo, \\ Que sou pobretão: \\ Em coisas mimosas \\ Sou mesmo um ratão.
}

Gama chega, até, a ironizar a situação do negro, apartado da riqueza, das ciências e das artes, através dos versos, explora, em tom irônico e crítico, o racismo acadêmico e epistemológico. Em tom satírico, apresenta-nos o lugar de um sujeito diaspórico, "desterritorializado", impossibilitado de produzir e consumir ciência, dada a sua capacidade intelectual e sua condição humana:

Ciências e letras

Não são para ti:

Pretinha da Costa

Não é gente aqui.

Sua poesia vem, assim, a destruir, denunciar e deformar o mundo de injustiças que o cerca. São análises de suas narrativas poéticas, onde ele próprio usava os conceitos de raça, identidade, modernidade e memória da escravidão para mediar a realidade social e as relações étnico-raciais, sendo a sátira social e política uma marca de sua personalidade.

\title{
CONCLUSÃO
}

Sendo assim, as memórias e diálogos de Luiz Gama e intelectuais negros da contemporaneidade e currículos escolares, leva-nos a relembrar que entre muitas batalhas vencidas, algumas marcaram como suas sucessivas vitórias nos tribunais na libertação de cativos, muitos escravizados 
ilegalmente, ultrapassaram as fronteiras de São Paulo, atraindo a atenção de muitas pessoas que sequer conheciam Luiz Gama, a quem talvez o reconhecesse apenas como abolicionista, sem considerar sua vertente poética literária para proclamar a justiça diante das injustiças sociais.

Portanto, a escolha da poesia satírica como estilo e recurso literário para ridicularizar a hipocrisia de uma sociedade letrata, intelectualizada, autoritária e escravocrata, apresentou-se como mais próxima do seu pensamento e luta social, visto que, em uma sociedade marcada pelas hostilidades raciais, ter acesso à cidade letrada pressupunha provar ter uma razoável instrução humanista e científica. A escrita poética em Gama também era uma arma, um exercício que procurava responder às injunções da sociedade escravista marcada pela hierarquização racial.

Seu fazer poético amplificou seu drama existencial, conferindo-lhe um alcance político, "pois ele passa a representar a condenação não apenas daquele ato isolado, mas da sociedade que o autoriza". Esse drama existencial refletia-se em sua vertente literária. Em seus escritos, Luiz Gama tinha o corriqueiro gesto de "anunciar a singeleza" de seus versos e solicitar complacência de seus leitores.

Escrever era um exercício que, no século XIX, respondia a necessidade de ordenar e instaurar a lógica da 'civilização' e que antecipava o sonho modernizador das elites criollas. A intelectualidade diaspórica de Gama reside na quebra da simetria e da cumplicidade entre língua, literatura, cultura e nação com a ordem geopolítica e as fronteiras geográficas. Uma vez que língua e literatura faziam parte de uma ideologia de Estado, cujo objetivo era manter a sociedade brasileira indivisa e harmônica, ainda que apresentasse posturas políticas nacionalistas, Gama representa uma literatura negra, mais precisamente uma antologia de cunho satírico-racial, que perturba a construção da comunidade imaginária homogênea que é a nação. 


\section{CONSIDERAÇÕES FINAIS}

Luiz Gama fez emergir ou tornou necessária, na historiografia romântica, uma nova linguagem poética da nação, uma linguagem extraoficial, que possibilitasse falar para o outro da sua existência. A partir de Trovas Burlescas de Getulino, as relações raciais passaram a constituir um tema literário de forma crítica.

Já para os sujeitos de cor que vivenciaram os efeitos da experiência colonial, "falar" era "existir absolutamente para o outro". Gama viveu uma experiência singular e histórica ao se auto representar. Isso não significa endossarmos o dogma de auto representação, em que somente os negros poderiam falar de si como parte integrante de grupo social subordinado racialmente. O espaço em que Gama adentrou o autorizou a expressar a visão de mundo de si e de todo um segmento sócio racial alijado da produção literária.

A ideia do negro coisificado contribuía para o não reconhecimento de suas capacidades poéticas. Primeiras Trovas Burlescas abre o espaço do outro em meio às relações de dominação, ganha o seu poder de significar, de estabelecer seu próprio discurso institucional e oposiciona.

A força persuasiva do texto criativo de Gama provém da sua experiência social diaspórica, de sua posição como sujeito desterritorializado, do entre lugar. Esses são os locais, os terrenos da literatura negra que fornecem os materiais para a representação poética e intelectual dos negros em seus desejos reprimidos historicamente.

Ainda hoje, a sua história é pouco falada e conhecida, assim como a de muitos outros (as) intelectuais negros. A comparação entre o quanto ele era conhecido naquela época e hoje é um abismo, pois esse desconhecimento diz respeito à invisibilidade do pensador negro.

Diante da singularidade dele como autor negro, nós vemos o peso da sua cor, vemos que o preconceito foi maior do que a vontade de enxergar o que ele era. Mas isso continua sendo perpetuado nos dias de hoje. 
Talvez o próximo passo seja valorizar tais produções e levar para os centros acadêmicos, currículos escolares e sociedade civil, porque não adianta ter toda uma pesquisa, uma interlocução entre intelectuais negros, se o material didático ainda é produzido em forma de síntese ou privilegiando alguns interesses hegemônicos.

Precisamos de currículos e de livros didáticos com autores que sejam mais comprometidos e responsáveis, com reflexões e atualizações intelectuais negras. Luiz Gama precisa chegar aos professores e alunos, ser conhecido pela população brasileira que encontrará nele e em outros intelectuais negros, inspiração e um exemplo a ser seguido, fundamental nos dias de hoje.

\section{REFERÊNCIAS}

AZEVEDO, E. de. O. de C. A trajetória de Luiz Gama na imperial cidade de São Paulo. Campinas: Editora da Unicamp, 1998.

BENTO, M. A. S. e CARONE, I. (Org.). Psicologia Social do racismo: estudos sobre branquitude e branqueamento no Brasil. Ed. Vozes, Petrópolis Rio de Janeiro, 2002.

BOBBIO, N. Os intelectuais e o poder: dúvidas e opções dos homens de cultura na sociedade contemporânea. São Paulo; UNESP, 1997.

CÂMARA, N. O advogado dos escravos - Luis Gama. São Paulo: Lettera, 2003.

CARONE, I.; BENTO, M. A. (orgs). Psicologia social do racismo: estudos sobre branquitude e branqueamento no Brasil. Petrópolis: Vozes, 2002.

DAMATTA, R. Digressão: a fábula das três raças, ou o problema do racismo à brasileira in Relativizando, uma introdução à Antropologia Social, Rio de Janeiro: Rocco, 1987.

FERREIRA, L. F. Com a palavra Luiz Gama. Poemas, artigos, cartas, máximas. Organização, apresentação e notas. São Paulo: Imprensa Oficial, 2011.

GAMA, L. Primeiras Trovas Burlescas e outros poemas. Introdução e organização de Ligia Fonseca Ferreira. São Paulo: Martins Fontes, 2000.

GAMA, L. A emancipação ao pé da letra. Gazeta do Povo, 28.12.1880. 
GOMES, N. L. A questão racial na escola: desafios colocados na implementação da Lei 10.639/03, Petrópolis: Vozes, 2008.

GOMES, N. L. Relações Étnico-raciais, educação e descolonização dos currículos. Currículo sem Fronteiras, v.12, Petrópolis: Vozes, 2012.

HALL, S. Da diáspora. Belo Horizonte: UFMG; Brasília, UNESCO, hooks, Bell. Black looks: race and representation. Boston: South End, 1992.

HOOKS, B. Intelectuais Negras. Revista Estudos feministas. N²/95. Vol.3. 1995.

JODELET, D. Os processos psicossociais da exclusão. In: SARAIVA, B. (org.). As artimanhas da exclusão: a análise psicossocial e ética da desigualdade social. Petrópolis: Vozes, 1999.

LÉVY, P. A Inteligência Coletiva: por uma antropologia do ciberespaço, São Paulo: Edições Loyola, 2007.

MENNUCCl, S. O Precursor do Abolicionismo no Brasil - Luís Gama. São Paulo: Companhia Editora Nacional, 1938.

MORAES, M. (Org.). Antologia da carta no Brasil: me escreva tão logo possa. São Paulo: Moderna, 2005.

NOVAES, A. O silencio dos intelectuais. São Paulo: Companhia das Letras, 2006.

SAID, E. Representações do intelectual: as palestras de Reith. Lisboa: Colibri, 1999.

SAID, E. Humanismo e crítica democrática. São Paulo: Companhia das letras, 2009.

SILVA, J. R. Luís da Gama e suas Poesias Satíricas. Rio de Janeiro: Ed. Casa do Estudante do Brasil.

Recebido em: 11 de fevereiro de 2019 Aprovado em: 30 de agosto de 2019 